MASTER

\title{
ENVIRONMENTAL ISSUES \\ RELATING TO FOSSIL ENERGY TECHNOLOGY OPTIONS
}

OFFICE OF TECHNOLOGY IMPACTS

Technology Assessments Division

\author{
Office of Environment \\ DEPARTMENT OF ENERGY \\ October 1979
}

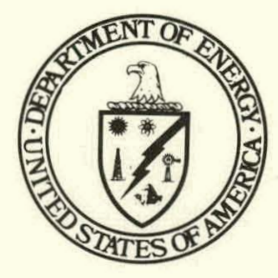




\section{DISCLAIMER}

This report was prepared as an account of work sponsored by an agency of the United States Government. Neither the United States Government nor any agency Thereof, nor any of their employees, makes any warranty, express or implied, or assumes any legal liability or responsibility for the accuracy, completeness, or usefulness of any information, apparatus, product, or process disclosed, or represents that its use would not infringe privately owned rights. Reference herein to any specific commercial product, process, or service by trade name, trademark, manufacturer, or otherwise does not necessarily constitute or imply its endorsement, recommendation, or favoring by the United States Government or any agency thereof. The views and opinions of authors expressed herein do not necessarily state or reflect those of the United States Government or any agency thereof. 


\section{DISCLAIMER}

Portions of this document may be illegible in electronic image products. Images are produced from the best available original document. 
DOE/EV-0065

UC-11, 41, 89, 90d, 90i

ENVIRONMENTAL ISSUES RELATING TO FOSSIL ENERGY TECHNOLOGY OPTIONS

OFFICE OF TECHNOLOGY IMPACTS

Technology Assessments Division

\author{
OFFICE OF ENVIRONMENT \\ DEPARTMENT OF ENERGY \\ October 1979 \\ WASHINGTON, D.C. 20585
}
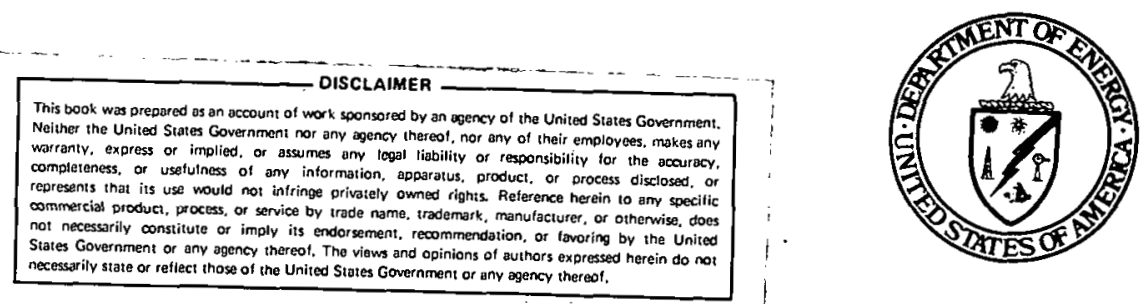


\section{Avatlable from:}

National Technical Information Service (NTIS) U.S. Department of Commerce 5285 Port Royal Road Springfield, Virginia 22161

Price: Printed Copy: $\quad \$ 4.50$ Microf 1che: $\quad \$ 3.00 .50$ 


\section{FOREWORD}

This report discusses environmental concerns of fossil technology options available to reduce oil imports. The technology options were addressed in a report prepared by the Office of Fossil Energy in August 1979.* The environmental report is a compendium of material found in the Environmental Readiness Documents, supplemented by further details of current research and development status and research requirements. It was prepared by the staff of the Fossil Technologies Branch, Technology Assessments Division, with assistance from other segments of the Office of Environment and incorporates comments from the Office of Fossil Energy.

An updated version will be issued later in Spring 1980. For further information concerning this document, contact Arnold Goldberg, Division of Technology Assessments, (301) 353-4406.

* Draft, "Report of Task Force on Fossil Technology Options to Reduce Oil Imports," Volumes I and II: Fossil Energy, August 1979. 


\section{THIS PAGE}

\section{WAS INTENTIONALLY LEFT BLANK}




\section{CONTENTS}

\section{Page}

INTRODUCTION . . . . . . . . . . . . . . . . . 1 COAL......................... 4 Direct Coal Firing . . . . . . . . . . . 4 Synfuel .................. 5 Coal End Use ............... 8 CONVERSION ....................... 11

Retrofit Technologies.............. 11 OIL . . . . . . . . . . . . . . . . 14

Oil Shale................ 14

Enhanced Oil Recovery - Heavy Oils. . . . . . 16

Enhanced Oil Recovery - Light Oils . . . . . . 18 GAS ......................... 21

Unconventional Gas Recovery ............ 21 


\section{INTRODUCTION}

The Office of Fossil Energy has prepared a report on fossil technology options available to reduce oil imports.* It identifies energy processes ready for immediate deployment (called first wave) and those that, after further development, would provide substantial benefits over the first wave. The latter (called second wave) technologies could be in commercial use in the late 1980s.

The status of environmental readiness for each of these fossil technologies is addressed in this report. Primary environmental concerns and environmental research required concurrent with fossil technology development and commercial operation are described herein, presented in conformance to the organization of the fossil options paper. In instances where environmental issues for related technologies are identical or nearly so, we have attempted to avoid redundancy, particularly where first- and second-wave technologies are based on the same underlying process.

Although many environmental concerns have been recognized and are being dealt with for each technology, some areas of concern must receive continued attention. These are briefly mentioned in this introduction. Further details, specific to each technology, are in the appropriate sections of the report.

Envirọmental, health, and safety (EH\&S) research on direct coal firing has focused on the identification of the products of combustion and gasification and their health and environmental effects. This has led to the establishment of a list of criteria pollutants and the regulation of their emission under the New Source Performance Standards (NSPS) of the Clean Air Acts. Investigations into the ecological effects of solid waste disposal techniques have also been made.

Research is continuing on both health and ecological effects. Having identified cancer-producing elements in airborne particulates, the Environmental Protection Agency (EPA) is developing a standard for respirable range particulates. The ecological effects of solid waste are being investigated under the Toxic Substances Control Act (TSCA) and Resource Conservation and Recovery Act (RCRA) to develop safe disposal standards. Health effects research is continuing to investigate products of combustion and emissions, as well as their transportation and transformation in the atmosphere.

With regard to the synthetic fuels, one of the major concerns is the health and safety aspects of the coal liquid products. It is known, for example, that some coal-derived liquids that have undergone only minimal processing or upgrading do contain carcinogens. EH\&S work initiated to date

*Draft, "Report of Task Force on Fossil Technology Options to Reduce Oil Imports," Vols. I and II: Fossil Energy, August 1979. 
in the Department of Energy (DOE) includes epidemiology, industrial hygiene, product and process stream characterization, and bioactivity studies of the solvent refined coal pilot plant. A similar coordinated effort was initiated at the University of Minnesota gasifier facility and has been planned at the Pike County facility, $\mathrm{H}$-coal pilot plant, and other major demonstration projects. Generic work initiated in this area includes solid waste leaching studies, wastewater control technology, transport and transformation of emissions in air and water, and characterization and bioassay of process streams.

With respect to oil shale, $R \& D$ efforts have focused on the identification of the potentially toxic components of retort effluents, on site-specific studies and measurements of particulate, gaseous, and fugitive emissions for control technology needs, and on leaching studies of a variety of spent oil shales to better understand how to control possible contamination of groundwaters.

In the enhanced oil recovery (EOR) area, for both heavy and light oil recovery, there has been research and development ( $R \& D$ ) in the characterization and measurement of gaseous pollutants, the identification and control of potentially toxic and/or carcinogenic chemical agents used, brine control to prevent groundwater or aquifer contamination, and the development of improved safety procedures.

In the unconventional gas recovery (UGR) area, a major interagency program by DOE, EPA, and the National Institute of Occupational Safety and Health (NIOSH) has been underway to measure and control the release of pollutants $\left(\mathrm{NO}_{\mathrm{X}}\right.$, unburned hydrocarbons, and particulate material) caused by diesel engines used in massive hydraulic fracturing.

Other efforts are underway to better understand the geologic stratigraphy and rock mechanics for western tight sands and Devonian shale areas to improve rock fracturing techniques, which would decrease the probability of accidental aquifer contamination and increase gas recovery as well.

-There are no proven environmental obstacles to commercialization of synfuel technologies. Adequate controls need to be adapted for water quality and solid waste disposal. In certain areas, the siting of plants that may produce additional emissions of air pollutants may be constrained because of existing air quality conditions (i.e., nonattainment).

In many cases, wastes and their leachates have not been fully characterized and therefore can pose additional environmental problems when TSCA and RCRA criteria are finalized and enfforced. The long-term effects from disposal sites and disposal practices remain to be demonstrated.

Although each technology discussed in this report has environmental concerns unique to the technology process (or site), they share requirements for generic environmental R\&D. In Table 1, specific technologies have been 
divided into eight groups: direct coal firing, synfuel, coal end use, conversion retrofit technologies,' oil shale, enhanced oil recovery (EOR)-heavy oil, and EOR-light oil and gas technologies. Broad areas of environmental $R \& D$ have been identified and include characterization, measurement, and monitoring; health effects screening; occupational health and safety; leaching of toxic substances; and land disturbance and reclamation.

The commonality of efforts across these technology areas has been highlighted. For example, the blanket requirement for characterization, measurement, and monitoring reflects the relative lack of a consistent data base on effluents from many commercial and pilot-scale technologies. By contrast, however, both oil and gas recovery technologies are well into commercial operation, but work remains in characterizing newly. developed injection materials and assessing the potential for modification of these materials underground.

Table 1 highlights major areas of required research. The absence of an entry under a specific category is not, however, an indication that all environmental concerns in the area have been resolved and that no work is required. Each discussion of a technology briefly addresses priority environmental issues, current status of knowledge, and an indication of work to be done. This information is derived primarily from the Environmental Readiness Documents and the Environmental Development Plans of the Office of Environment.

Table 1. Principal Environmental R\&D Areas of Concern

\begin{tabular}{|c|c|c|c|c|c|c|c|c|}
\hline \multirow[t]{2}{*}{ '. } & \multicolumn{3}{|c|}{ COAL } & \multirow[b]{2}{*}{$\begin{array}{l}\text { CONVERSION } \\
\text { RETROF IT } \\
\text { TECHNOLOGIES }\end{array}$} & \multicolumn{3}{|c|}{ OIL } & \multirow[t]{2}{*}{ GAS } \\
\hline & $\begin{array}{l}\text { DIRECT } \\
\text { COAL } \\
\text { FIRING }\end{array}$ & SYNFUEL & $\begin{array}{l}\text { COAL } \\
\text { END } \\
\text { USE }\end{array}$ & & $\begin{array}{l}\text { OIL } \\
\text { SHALE }\end{array}$ & $\begin{array}{l}\text { EOR - } \\
\text { HEAVY } \\
\text { OIL }\end{array}$ & $\begin{array}{l}\text { EOR - } \\
\text { LIGHT } \\
\text { OIL }\end{array}$ & \\
\hline $\begin{array}{l}\text { CHARACTERIZATION, } \\
\text { MEASUREMENT } \\
\text { MONITORING }\end{array}$ & 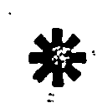 & & & & & & & \\
\hline $\begin{array}{l}\text { HEALTH EFFECTS } \\
\text { SCREENING }\end{array}$ & & & & & & & & $i 1$ \\
\hline $\begin{array}{l}\text { OCCUPAT IONAL } \\
\text { HEALTH \& SAFETY }\end{array}$ & & & & & & & & \\
\hline $\begin{array}{l}\text { LEACHING OF TOXIC } \\
\text { SUBSTANCES }\end{array}$ & 点 & & & & & & & \\
\hline $\begin{array}{l}\text { LAND DISTURBANCE } \\
\text { \& RECLAMATION }\end{array}$ & & & & & & & & \\
\hline
\end{tabular}




\section{COAL}

DIRECT COAL FIRING

\section{Concern}

Direct coal firing and advanced scrubbers with direct coal firing are the major concerns in coal usage. The primary environmental concern associated with direct coal usage is control of criteria pollutants, i.e., $\mathrm{SO}_{\mathrm{X}}$, $\mathrm{NO}_{\mathrm{X}}, \mathrm{CO}, \mathrm{HC}$, and particulates. Direct coal firing produces solid residuals of ash, fly ash, and sludges from flue gas desulfurization (FGD). These must be disposed of in an environmentally acceptable manner to prevent water contamination. Some regenerable FGD systems produce soluble salts. For advanced systems that produce a sulfur product, there is the problem of the disposal or end use of that product.

Additional environmental concerns to address prior to commercialization of advanced scrubbers with direct coal firing are

-. Impact on combustion products by derating of the boiler and

- Soluble sodium loss in sludge disposal associated with double alkali.

\section{Status}

"Proper combustion of coal in boilers will reduce concentrations of $\mathrm{CO}$, $\mathrm{HC}$, and photochemical oxidants to negligible levels. A class of combustion controls known as combustion modifications (e.g., staged combustion, lean excess air combustion, and burner design) may effectively reduce $\mathrm{NO}_{\mathbf{x}}$ concentrations to acceptable levels. Particulates can be controlled with electrostatic precipitators and fabric filters.

According to recent NSPS, scrubbing is required for all coals. This removal process can be divided into two major categories: nonregenerative and regenerative. In the former category, an agent (e.g., lime or limestone) combines chemically with $\mathrm{SO}_{2}$ from the flue gas, and the product is then removed from the system and discarded. This presents large-scale solid waste and water pollution problems, and the satisfactory (environimentally and economically) disposal of these residue products is a subject of prime importance.

In advanced FGD techniques, $\mathrm{SO}_{2}$ is removed from flue gas through regeneration, and sulfur (possibly as $\mathrm{H}_{2} \mathrm{SO}_{4}$ ) is recovered. FGD systems create solid waste and, to a lesser extent, water pollution problems. Smaller, cheaper, less-energy-consuming systems, such as the double alkali, are under development to reduce these effects. The technology tested in pilot plants is being tested at demonstration or small commercial scale. However, economics, adaptability to utility sizes, and reliability are unproven, and operation with limestone needs to be demonstrated. 
Contemporary application of solid waste disposal, such as fly ash from direct combustion, has been intensely pursued. But additional work is required to ensure that currently acceptable techniques adequately address the unique characteristics of advanced scrubber sludges, fly ash containing new dry injection materials, and bed materials from various forms of fluidized bed combustion.

\section{$\underline{R \& D \text { Requirements }}$}

Research in particulate control is needed to extend the practicability of conventional particulate control systems (electrostatic precipitators (ESPs), scrubbers, and fabric filters) to abate respirable range particulate emissions. This effort should include both evaluation of devices for use at higher efficiency levels and modification of devices to make them suitable for operation under rigorous conditions for operation on unproven but essential applications.

Modification of electrostatic precipitator techniques for use when burning low-sulfur, high-ash coals is being studied. Efforts must be made to determine control parameters and assess control techniques for $\mathrm{NO}_{\mathrm{x}}$ formation and decomposition in combustion zones, and flue gas streams. Âdvanced techniques for trace elements, organics, and $\mathrm{NO}_{\mathbf{x}}$ control may be needed to meet future regulations. An assessment of capabilities and costs of fabric filtration and electrostatic precipitation to control various levels of particulates is necessary.

Limestone and lime FGD systems will remain predominant for several years. Continued effort should be focused on increasing effectiveness and reducing costs. Alternate scrubber types accommodating increased gas velocities should be considered. Improved understanding is needed for mist eliminators and reheaters that operate under conditions (configurations, gas, and liquid flow patterns, etc.) associated with scrubbers.

Environmental, health, and safety research is continuing to investigate the health and ecological effects of airborne emissions and solid waste. This includes research in the transportation, transformation, and fate of pollutants and their health effects. Investigation of leachates from solid wastes is underway to determine the ecological effects and environmentally acceptable disposal techniques.

SYNFUEL

\section{Concerns}

Surface gasification, indirect liquefaction, and direct liquefaction are the major concerns in synfuel processes. The significant environmental concerns generally associated with the commercial deployment and 
development of synfuel processes are

- Air quality degradation resulting from process operational releases, fugitive emissions, accidental releases, raw material/product handling, storage, and transport;

- Disposal of byproducts and solid waste from process and environmental control technology operation;

- Contamination of surface waters and groundwaters from release of liquid pollutants, spills, and solid leachates;

- Occupational health effects from exposure to low levels of hazardous, toxic, and/or carcinogenic process-related material; and

- Storage, transportation, and eventual end use of liquid products that may contain toxic, hazardous, and carcinogenic materials.

The degree to which these general concerns apply to a specific technology depends on the environmental characteristics of the final product and on the characteristics of those materials within the process.

\section{Status}

There may be regional air quality, water quality, water availability, or solid waste disposal constraints to siting facilities in areas where proven sources of coal and product markets are located. Such siting constraints may have to be resolved by shifting the site, developing specific control technologies, or requesting limited waivers on specific regulation.

Products, process streams, emissions, and accidental releases from direct liquefaction synfuel processes contain polynuclear hydrocarbons, aromatic amines, nitrogen- and sulfur-containing heterocyclic compounds, and trace metals that are known or suspected to be carcinogenic, mutagenic, teratogenic, or toxic. Health and ecological effects research of the direct liquefaction process streams, emissions, and products is in its infancy. Thus, no conclusive statements or risks associated with production, transportation, handling, and end use of these materials can yet be made. However, previous epidemiological and animal studies have indicated that certain coal derived liquids process carcinogenic properties and current direct liquefaction process product screening tests have shown that they have mutagenic activity, which must be further confirmed with additional animal tests.

Indirect liquefaction processes consist of decomposing coal to gaseous products in a gasification step and then recombining the gaseous products into liquid (petroleum) products in the second step. The waste products from the second step may pose health and ecological effects concerns similar to those of the direct liquefaction processes. It is expected that the 
products and process streams of this second step would have fewer adverse effects than the direct liquefaction process counterparts. However, no work has been initiated to determine these effects to date. The health and ecological effects of the first step, coal gasification, will vary with the process. Lurgi pressure gasifiers produce liquid byproducts that contain heavy oil fractions like tar and are known to have carcinogenic and other toxic effects. They will have to be appropriately handled, used, or disposed of. The atmospheric Winkler process would have similar byproduct problems. However, the high temperature atmospheric Koppers-Totzek gasification process will produce negligible byproducts, and the only major concern may be wastewater treatment.

The fate of trace metal and compounds in indirect and direct liquefaction processes have yet to be determined and work in this area is in its infancy.

Controls of ambient levels of the materials mentioned above under direct liquefaction sections and of other toxic materials like carbon monoxide and carboyl sulfide are as yet unknown. Limited data for the controls and effects available from similar industries are not easily and accurately applicable to the coal liquefaction facilities.

The disposal of solid wastes and sludges using available control technology can meet applicable solid waste disposal regulation standards. However, the ultimate composition of solid wastes from the synfuel processes is not completely known. The application of finalized RCRA and TSCA standards may raise questions about the adequacy of current disposal techniques and may require improved control technology development and procedures.

Most synfuel processes may be designed as closed loop systems (i.e., zero or minimal discharge of liquid wastes). Such systems are in operation for processes in other industries, but they have not been demonstrated for synfuel processes at commercial scale to meet current and projected regulations. The concern here is the characteristics of the blowdown or bleed streams and their final disposal.

\section{R\&D Requirements}

Regional air quality and water quality studies of the areas where major coal resources and major users are located should be undertaken to facilitate siting of the projected number of synfuel plants.

Occupational health effects of the synfuel industry and the associated user industries are a major concern for accelerated synfuel production. Programs to evaluate worker exposure to process materials, as well as epidemiological and animal studies to gain knowledge of specific effects, are required. An epidemiology and industrial hygiene study of commercial coal gasification and indirect liquefaction facilities (in Europe and Africa) should be undertaken to identify and resolve occupational (as well as public) health 
effect concerns specifically and in a timely manner for the accelerated synfuel commercialization plans.

Solid wastes from large-scale facilities should be fully characterized and their leachate characteristics determined so that appropriate control technology can be adopted or developed to minimize health and ecological effects in accordance with current and projected RCRA and TSCA regulations.

The ability of the synfuel plants to operate as closed-loop systems should be demonstrated, and the characteristics of any blowdown or bleed systems should be determined for large-scale facilities. This work is necessary for the adoption or development of appropriate control technology to minimize health and ecological effects for current and projected EPA water quality regulations.

It is also very important that a study of the mobility, transport, and transportation of all criteria (e.g., $\mathrm{SO}_{\mathrm{x}}$ ) and noncriteria (e.g., PNA) emissions (gaseous, liquid, and solid) from the large-scale synfuel industry be undertaken. These studies are short range for the resolution of concerns in environmental impact statements as well as long range for the resolution of the effects due to low-level exposures.

\section{COAL END USE}

Coal gas firing, conversion to clean fuels from coal in utility boilers, and switching to coal-derived gas for a gas turbine combined cycle are the major concerns of coal end-use technologies. Significant environmental concerns associated with the operation of these technologies are

- Generation of large amounts of $\mathrm{NO}_{\mathbf{x}}$ from high combustion temperatures;

- $\therefore$ Characterization of combustion byproducts such as cyanide, arsenic, and carbon monoxide;

..

Removal of particulate material from the fuel feed to meet proposed standards for particulate emissions; and - $m$ High levels of noise originating at the intake and exhaust of the
gas turbine.

$\underline{\text { Status }}$

Recent burn tests of solvent refined coal (SRC-II) liquids at Con Edison in New York revealed that $\mathrm{NO}_{\mathbf{x}}$ emissions were 70 percent greater than those from combustion of low-sulphur No. 6 fuel oil, but that emissions throughout the load range were under the 400-ppm limit for coal-derived fuels proposed by EPA in September 1978. Particulates from hydrocarbons were less than from No. 6 fuel oil. 
Tests have shown that $\mathrm{NO}_{\mathbf{x}}$ emissions can be reduced by hydrotreatment of the liquid or by using a two-stage combustion process. $\mathrm{NO}_{\mathrm{x}}$ emissions may be reduced further by blending SRC-II with petroleum-based oils containing lower amounts of fuel-bound nitrogen and then firing in a two-stage combustor.

The current and most common method for $\mathrm{NO}_{\mathrm{x}}$ control in the gas turbine, water injection, is not considered to be an optimal approach for new turbine technology, due to inherent efficiency loss and high consumption of treated water. The $\mathrm{NO}_{\mathrm{x}}$ reduction techniques of combustion control, combustion modification, and catalytic combustion are considered more desirable approaches. Although these techniques are conceptually applicable, they have not yet been applied and confirmed in these systems.

Emissions of $\mathrm{SO}_{2}$ from system operation will be reduced by the removal of sulfur from the fuel exiting the gasifier. When hot gas sulfur removal processes become available, they will almost certainly be applied. Their ability to achieve required levels of sulfur in an environmentally acceptable manner must be confirmed.

The assumption that particulates exiting the gasifier will be removed in the gas cleanup process along with the sulfur is consistent with current process characteristics and development for both cool and hot gas cleanup systems. Although techniques applied may differ from a hot gas stream to a cool gas stream, the degree of particulate removal required will remain essentially the same. Although very low mass concentrations of particulates can be expected in the fuel feed, and thus in the turbine exhaust stream, both trace element constituents and physical size distribution must be characterized.

Although there will be a substantial amount of solid waste associated with the operation of the complete gasifier-turbine-steam cycle, this will stem primarily from operation of the gasifier. This material should be comparable in all respects to the solid wastes of other low-Btu gasifiers using the same coal feedstock and degree of gas cleanup. Concerns for disposal of this material include the trace element and organic constituents retained in the gasifier. If water injection for $\mathrm{NO}_{\mathrm{x}}$ control were to become necessary, the suitable disposal of sludge from the water treatment process would require attention. Conventional disposal techniques should apply.

Gasification of coal will vaporize trace elements and may form toxic compounds, and quantities of carbon monoxide may remain. Uncontrolled burning of coal gas may expose the industrial workers and general public to unregulated toxic substances.

A potential exists for transmission of high levels of noise from a turbine facility of the size proposed, both from the turbine structure and from the exhaust gas stream exiting the system. Addition of a stream bottoming cycle may reduce noise originating from the exhaust stream to an acceptable level. 


\section{R\&D Requirements}

Application and optimization of combustion modification techniques and catalytic combustion for new high-temperature turbine combustors are needed for $\mathrm{NO}_{\mathrm{x}}$ control. Development of processes and the adequate removal of sulfur will be required for $\mathrm{SO}_{\mathrm{x}}$ control.

Additional burn tests are necessary to characterize the organic and inorganic content in the coal-derived liquids. Research should be directed toward improvement of end-use control technology, determination of health and safety risks for personnel, evaluation of ecological effects from transport spills, determination of long-term health effects of populations exposed to liquefaction combustion products, and determination of short-term health effects from population exposure to materials released accidentally during any transportation spills. Recommendations should be formulated (and. updated as research results become available) for procedures for crisis response teams or centers that could be responsive to emergency situations resulting from spills and other exposures. 


\section{CONVERSION}

\section{RETROFIT TECHNOLOGIES}

\section{Concerns}

Coal/oil mixtures (COM) and conversion to coal firing (fluidized bed combustion $(F B C)$ ) are the major concerns of retrofit technologies. Significant environmental concerns associated with the operation of these technologies are as follows:

- Significant amounts of solid waste will require disposal.

- Leachates from spent sorbent exceed the limits in existing or proposed EPA secondary drinking water standards for calcium, sulfate, and total dissolved solids and the water quality standard for $\mathrm{pH}$. These may affect local water supplies.

- Coal-fired atmospheric fluidized bed combustion (AFBC) units and COM units that replace existing or new oil- and gas-fired industrial facilities will be located in metropolitan areas having dense populations and aggravated air quality problems, especially fine particulates that may transport toxic trace metals and or ganics and could adversely affect human health.

\section{Status}

COM will be retrofitted to existing utility and industrial boilers. Preliminary test results indicate that combustion of COM can release significant quantities of fine particulate matter upon which organics and trace metals such as arsenic, cadmium, beryllium, and mercury may be absorbed. Fly ash particles are predominately below 10 microns in diameter and will not be efficiently controlled by inertial removal devices such ascyclones. Retrofit applications of COM to existing oil or gas units will require installation of electrostatic precipitators. Due to low ionization, ESPs may not perform well on low-sulfur COM fly ash and will probably not perform adequately to meet the stringent levels of control $\left(0.03 \mathrm{lb} / 10^{6} \mathrm{Btu}\right)$ proposed in the revised NSPS. Fabric filters will probably be necessary to meet this level. Fly ash stickiness will affect baghouse performance, requiring special design considerations.

Emissions of $\mathrm{SO}_{2}$ are expected to be inherently controlled through the use of low-sulfur coal and oil. Effectiveness of dry sorbent FGD with high-sulfur coal oil is currently being evaluated for COM. Emissions of $\mathrm{NO}_{x}$ have been demonstrated to be controlled through the use of conventional combustion modification techniques. Amounts of $\mathrm{NO}_{\mathbf{x}}$ produced by $\mathrm{COM}$ combustion appear to be less than amounts produced from combustion of oil or coal alone. 
A major uncertainty with COM technology is the possible need to use chemicals as mixture-stabilizing agents, such as starch- or soap-based chemicals; others are proprietary hydrocarbon compounds whose compositions are not known. Because the compositions of the additives are not known, their behavior during combustion is also uncertain. They may directly form new hazardous air pollutants, catalyze the formation of new pollutants, or hinder emission control measures for criteria pollutants.

Combustion efficiencies of COM are high, with unburned carbon in the range of 0.2 to 0.6 percent. If retrofitting of existing oil- or gas-fired units to COM is not properly conducted to maximize combustion efficiency, soot and polynuclear aromatic hydrocarbons may be emitted.

Fly ash collected from COM units should resemble a mixture of ash from pulverized coal-fired units and oil ash. Leachates from ash may contain low levels of trace metals and organics, and the concentrations of some may exceed acceptable levels under RCRA or the Safe Drinking Water Act. The possible presence of residues from chemical stabilizing agents may affect leaching behavior and subsequent requirements for disposal.

Several industrial-sized AFBC units are being operated to determine steady-state operating parameters, and EPA and DOE have begun to collect and analyze emissions from these units.

FBC generates large volumes of spent sorbent solid wastes and has a tendency to produce large volumes of particulate. Current information indicates that FBC particulate is not significantly different from fly ash and can be controlled by baghouses. The solid wastes are subject to leaching and may contaminate local groundwater.

EPA and DOE have ongoing projects to evaluate solid waste disposal techniques, leachates from solid waste, and alternate uses of the material.

\section{$\underline{R \& D \text { Requirements }}$}

Leachates from spent FBC sorbent have low levels of trace metals and organics, according to preliminary tests. However, toxic metals, such as arsenic, mercury, cadmium, lead, and vandium, may exceed concentrations in wastes that would be acceptable under RCRA. Under that act, criteria for solid wastes (or hazardous wastes) containing these species have not been promulgated at this time and are not expected in the near future. W/hatever criteria are developed, it is reasonable to assume that some relatively stringent control of these wastes must be employed. It will be necessary to dispose of solid wastes offsite, because most of the FBC facilities will be located in urban areas where disposal of such wastes may be prohibited due to local laws, RCRA, or land availability.

DOE research is also underway to investigate the products of combustion of each COM mixture to determine if any new or unique toxics are present as a result of stabilizing agents. Joint DOE, EPA, State, and 
industry research is underway to monitor the current New Salem, Massachusetts, COM demonstration for compliance with NSPS and identification of emissions. 


\section{OIL}

OIL SHALE

Concerns

Surface retorting and modified in situ retorting pose the major environmental concerns of oil shale technology. The environmental concerns facing the commercial expansion of oil shale by these methods are as follows:

- Air quality in the region can be degraded from mining operations and the retorting process emissions, i.e., particulates, hydrocarbons, and $\mathrm{SO}_{2}$.

- Local water resources can be affected due to the demand for clean process water, water to remove process effluents, and mine dewatering.

- Mining and disposal of shale will create land disturbances of large magnitude (dust control and reclamation), potential for accumulation of toxic substances in vegetation, and potential contamination of groundwaters and surface waters from runoffs.

- For modified in situ retorting, potential aquifer disruption and contamination exists. Long-term hydrological disturbances are possible in arid and semiarid areas and may deter large-scale development in Utah and Colorado.

Status.

During oil shale mining and processing operations, a potential exists for production and release of both criteria pollutants (e.g., $\mathrm{CO}, \mathrm{NO}_{\mathrm{x}}, \mathrm{SO}_{2}$, hydrocarbons, particulates, photochemical oxidants) and noncriteria pollutants (e.g., !trace metals, polyaromatic hydrocarbons).

$\therefore$

Information on modified in situ and in situ processes stems from industrial Occidental and Geokinetics field tests and pilot retorts operated by DOE. Fugitive gaseous emissions have not been studied in detail, existing control.technology has not yet been applied, and additional work is needed in these and other areas.

Control of backflood water in below-ground retort operations will be necessary, but difficult and expensive to achieve. There may be groundwater problems from below-ground retorting processes. 
There is a high potential for affecting water availability and quality in the Piceance Creek Basin. A Water Resources Council assessment indicates that the water supply from the Upper Colorado River would be adequate for about 1.3 million barrels per day of oil production.

Raw and spent shale storage piles can increase salt loads and otherwise contaminate groundwater and surface water bodies; mine dewatering and shale processing effluents may contain contaminants that could affect ecology and human health.

\section{$\underline{R \& D \text { Requirements }}$}

Work is currently in progress to determine potentially harmful gaseous and particulate emissions. This work involves assessing control requirements and options, investigating land reclamation, spent shale disposal, and subsidence.

An experimental program is underway to demonstrate environmentally acceptable methods for habilitating retorted shale and to quantify recovery times, success of vegetation efforts, mobility of toxic substances, and other key ecological processes. Experimental plots have been established on retorted shale waste to evaluate salt migration, water balance, chemical transformation, and migration rates. Additional effort includes evaluation of toxic substances produced by shale processes and their movement in retorted shale.

Field and laboratory research is planned to determine the geochemical behavior of trace elements produced in retorted shale. Studies of mobility in soil, sediment, and geological materials as well as uptake by plants and animals are scheduled.

Extensive water resource investigations are being conducted throughout the Piceance Creek Basin to measure the chemical, physical, and biological parameters of surface waters and to evaluate potential effects on fish and wildlife population. Health effects studies are in progress to determine potential mutagenic and carcinogenic hazards from oil shale development. Tests of new shale, spent shales, stream waters, spent shale leachates, chlorinated drinking supplies, and wastewaters with spent shale leachate are being performed to establish toxicity levels. Additional health effects studies will determine the toxicity of refined shale oil products. Further work is needed on petroleum hydrocarbons and constituents that may accumulate in the marine food chain. 
Methods for prevention of groundwater contamination by backflooding must be developed. Backflood groundwater may escape into adjacent groundwater aquifers carrying contaminants. The variables that affect the quantity and quality of retort water are poorly understood.

The degree of ventilation required for in situ mines is not defined. Controls for inhalation protection from other industries must be adapted to the oil shale industry.

A potential clearly exists for emission of both toxic and carcinogenic materials. However, information on such concerns as toxicity and carcinogenicity from various products or end uses is lacking at this time.

Other needed research includes definition of ventilation required for in situ mines, development of individual dose monitors for organic residuals, risk analyses, and hygiene program guidelines.

\section{ENHANCED OIL RECOVERY - HEAVY OILS}

\section{Concerns}

Heavy oils and mine-assisted steam flooding of heavy oils are the major concerns of heavy oil enhanced oil recovery. The environmental concerns facing the commercialization of this technology are as follows:

- Potential air pollution hazards. These arise from both the operation of direct-fired boilers (in particular, $\mathrm{SO}_{\mathbf{x}}, \mathrm{NO}_{\mathbf{x}}$, and particulates) needed to produce the steam and the contaminated effluent steam that is vented (in particular, $\mathrm{H}_{2} \mathrm{~S}$ ).

- Water contamination. The extraction process results in significant quantities of water (brackish and saline) that must either be collected at the surface or reinjected into the ground. Inadequate containment may result in surface water contamination by brine or penetration of an aquifer.

- Water availability. Steam flooding processes require large amounts of water, and although current uses are accommodated within the framework of local and State water allotments, the future use of steam drive may encounter difficulties in water allotment,

it particularly in the semiarid western areas of the United States.

- Occupational health and safety. The danger of possible fire and explosions, exposure to asphyxiating gases $\left(\mathrm{SO}_{2}, \mathrm{NO}_{\mathrm{x}}, \mathrm{H}_{2} \mathrm{~S}, \mathrm{CO}\right.$, $\mathrm{CO}_{2}$ ), chemical agents, high temperature/high pressure operating conditions, noise, and transportation accidents always exists. 
Contamination of surface and subsurface water through accidental release. Potential use of toluene, a known carcinogen, in connection with the steam injection process cuuld cause such contamination.

$\underline{\text { Status }}$

Air pollution problems can be reduced or eliminated by utilizing other energy sources for producing steam. For example, the Office of Fossil Energy is funding a project to use solar heating for steam drive. The use of electricity would be prohibitively expensive for producing steam. However, adequate control technology is now available as add-on scrubbers. Another possible mitigation procedure would be the reinjection of the combustion gases with steam to enhance oil recovery and reduce air pollution. (DOE currently has a contract to test the feasibility of this approach.)

Although accidental spills or release of brine cannot be controlled, preventive measures can be used, e.g., ponded storage areas with monitoring to determine rate and direction of flow.

\section{R\&D Requirements}

Current and planned DOE R\&D in the air quality area include improved air-monitoring procedures, evaluation of air quality data around facilities, and development of improved atmospheric transport models to predict fate and dose to man and the ecosystem. Work is in progress to develop remote and in situ instruments to detect toxic substances, suspended particulates, carcinogenic vapors in ambient atmospheres, polycyclics, and other organic pollutants.

Current and planned DOE and other agency efforts in the water quality area include examination of environmental control technology for improved brine control, improved characterization of aqueous effluents from oil refining sources, study of the biodegradation of EOR chemical compounds, and study of the effects of mixed petroleum hydrocarbons in marine fishes.

Although needed $R \& D$ in occupational health and safety includes bioassays, dose-response studies, and specific safe handling procedures for the chemicals used in the various EOR technologies, much effort is already underway in these areas both by DOE and other agencies. This includes developing screening tests for hydrocarbon carcinogenicity and mutagenicity analysis of molecular processes involved in the carcinogenic action of polycyclic aromatic hydrocarbons, and evaluation of the influence of inhalation of acid aerosols and particulates.

The major problem with mine-assisted steam flooding will be in safely drilling horizontal wells from the mine shafts, and little experience is available in this area. Insufficient sand control could result in well plugging. Mining the horizontal shafts through oil and water zones will also be difficult and may require modification of existing technology or development of entirely new methods for shaft sinking under these conditions. 


\section{Concerns}

Light oils, chemical flooding, and gas or $\mathrm{CO}_{2}$ flooding (first wave), and micellar polymer and alkaline flooding (second wave) are the major concerns of light oil enhanced oil recovery. Light oils are extracted by either chemical flooding or miscible gas $\left(\mathrm{CO}_{2}\right)$ injection, which could result in chemical contamination of groundwater and aquifers.

Because mobility controlled $\mathrm{CO}_{2}$ flooding, micellar polymer, and alkaline flooding processes involve the use of chemical injection for oil recovery, environmental concerns are similar. Major concerns facing commercialization of these processes, which are similar to the chemical and $\mathrm{CO}_{2}$ flooding, are as follows:

- Use of chemical flooding with high molecular weight polymers mixed with water poses a major potential water contamination problem. The possibility of accidental leakage from corroded or inadequate casings or connections, unlocated abandoned wells, and accidental spills or escape from surface impoundments make this a serious concern with respect to contamination of shallow (freshwater) aquifers. In addition, large volumes of water and oil emulsions mixed with brine must be cleaned up and disposed of.

- Transport, storage, and use of chemicals impose a potential danger of accidents and accidental spills when using the chemical flooding process.

- Local water resources can be affected due to the demand for water to support the chemical flooding process (up to 20 barrels of water for each barrel of oil recovered).

- Handling, transport, and injection of $\mathrm{CO}_{2}$ involve potential danger to workers from accidental exposure to $\mathrm{CO}_{2}$ and from in situ chemical reactions.

0

Transportation, storage, and handling of large amounts of salt and caustics in the alkaline flooding process and toxic chemicals in the micellar polymer process pose a danger through leakage and

: accidental spills.

$\underline{\text { Status }}$

Chemicals injected into oil wells dissipate into rock strata that are generally far below drinking water aquifers. However, possible accidental leakage from corroded or inadequate casings or connections, unlocated abandoned wells, and accidental spills or escape from surface impoundments make contamination of shallow (freshwater) aquifers a serious concern. In 
addition, large volumes of water and oil emulsions mixed with brine are produced in EOR processes and must be cleaned up and disposed of in an environmentally acceptable manner. At present, industry is handling this to meet current standards. However, injected chemicals are not well characterized, and toxicity, carcinogenicity, and mutagenicity of all the components and overall mixtures have not been determined. The use of large volumes of corrosive alkali solutions in alkaline flooding poses an occupational health hazard.

DOE initiated a study of the carcinogenicity of micellar chemicals in early 1979. Further work will be supported by DOE's Office of Environment to determine toxicity, carcinogenicity, and mutagenicity of chemicals not yet investigated.

Industry has, over the years, done much to minimize dangers from fire and explosions and to minimize worker exposure. Casing design has also been improved, and effort is in progress to increase knowledge of geologic stratigraphy and related properties (porosity, permeability, rock structure). In addition, there has been an increased effort, in the case of tertiary oil recovery using old wells, to better test the integrity of these wells before use to reduce chances of casing wall rupture.

\section{$\underline{\text { R\&D Requirements }}$}

If $R \& D$ - on the toxicity and carcinogencity of micellar injection chemicals and other chemicals injected into the ground reveals a highly toxic, highly carcinogenic, or mutagenic compound, the chemical industry will probably generate new formulations omitting this compound. At present, certain surfactants such as alkyl aryl sulfonates and polycyclic sulfonated hydrocarbons are used, although they are known carcinogenic agents. Industry to date has carefully followed health and safety procedures to ensure minimal risk to workers. However, danger to workers and possible contamination of the groundwater from accidental spills of such chemicals exist. Detailed toxicity studies are required to determine risks because many of the additives and their degradation or transformation products are not well defined.

Although there is a current effort on the part of DOE and other agencies in the areas of chemical bioassay studies, chemical-biological transformation studies, and dose-response studies, more effort is indeed needed and is planned. These ongoing and planned efforts include (1) the characterization of the chemicals used in EOR and their chemical and microbiological transformation in soils and water and (2) the determination and modeling of the environmental transport and fate of chemical and thermal releases to surface and subsurface waters to predict dose to man and the ecosystems. In addition, screening efforts for acute toxicity in effluent samples will continue. 
Work is needed to establish procedures for safety precautions and control of EOR chemicals and to develop a plan to deal with major accidental releases. Finally, there is a planned assessment of the hazards of $\mathrm{CO}_{2}$ transport, storage, handling, and injection for EOR aimed at the development of more stringent safeguards for $\mathrm{CO}_{2}$ and improved handling and container devices.

Possible application of the Safe Drinking Water Act of 1974 to groundwater under and around EOR sites could have a major impact on the commercialization of EOR technology by adding significant costs for the environmental control measures. An additional area of concern is the designation of "chemical injection" as a significant "new" use under Section 5 of the Toxic Substances Control Act. Such a designation would require up to 2 years of testing based on TSCA criteria. 


\section{Concerns}

Tight gas formations and Devonian shale gas recovery are the major concerns of unconventional gas recovery. Environmental concerns facing the commercial development of these resources include

- Siting and construction of a support network of new pipelines to transport the gas, particularly for Western tight gas sands;

- Possible water pollution of underground and surface waters due to massive hydraulic fracturing operations;

- Water availability, which could be a problem, particularly in the semiarid Western States, due to the quantities of water required for massive hydraulic fracturing;

- Contamination of effluents with chemical constituents due to underground detonation of chemical explosives; and

- Accidental mixing or improper handling aboveground of explosives, resulting in a hazardous situation for site workers.

$\underline{\text { Status }}$

Application of unconventional gas recovery techniques to potential target gas deposits, particularly the tight gas sands, requires drilling of new wells in areas that have not previously contained gas wells. To gather gas produced from new wells and transport it to locations for use, a network of new pipelines will be required. Current estimates place requirements at 3300 miles of large-diameter pipe by 1985 , in addition to extensive intrafield gathering and connecting network. Siting and construction of such pipeline networks would have a major environmental impact.

Detonation of chemical explosives underground and injection of massive hydraulic fracturing fluid chemicals may result in contamination of the gas to be recovered. Some of these reaction products may initially be produced with the gas and will require removal and disposal.

A potential does exist for accidental penetration of aquifers and accidental spills and releases of fracture fluids to surface waters. Although no evidence currently exists to show that serious contamination of water resources will result from EGR operations, field monitoring and evaluation are required. 
Fugitive emissions and startup activities may pose some concerns in initial phases. For example, conventional gas well fracturing procedures typically require three to six diesel-powered pumping units (approximately $700 \mathrm{hp}$ each) operating for a period of up to 1 hour total, whereas massive hydraulic fracturing procedures typically require 15 to 20 diesel-powered pumping units, operating for a total period of up to 24 hours. Concurrent with this increased demand for pumping capacity is the need for increased storage capacity for fracture fluids and liquid wastes.

\section{R\&D Requirements}

Pipeline construction is one of the most important concerns in unconventional gas recovery (UGR) development and, as such, has already received attention. Environmental impact analyses are currently being prepared by DOE, and an evaluation study of environmental protection laws and regulations pertinent to UGR was completed in 1975.

Potential air pollution from the diesel engines and turbines required in massive hydraulic fracturing will result from the release of such pollutants as $\mathrm{NO}_{X}$, unburned hydrocarbons, and particulate material. Intensive R\&D effort is in progress in this area by DOE, EPA, and NIOSH. This involves determination of the mass emission rates and chemical composition of respirable-sized particulates, detection and "confirmation of the toxic potential of diesel exhaust fractions by in vitro and in vivo bioassays, and evaluation of synergistic interaction between diesel exhausts and fugitive emissions from UGR operations. In chemical ,explosive fracturing, the components of the explosive are not dangerous until mixed underground. However, improper handling or accidental mixing could result in an occupational hazard. A DOE effort is planned to assess the safety and environmental control issues of storing and handling explosives used in UGR; $\mathrm{NIOSH}$ involvement is anticipated. 


\section{United States}

Department of Energy

Washington, DC 20545

Official Business

Penalty for Private Use, $\$ 300$
Postage and Fees Paid

U.S. Department of Energy

DOE-350

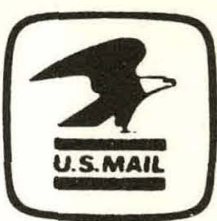

